\title{
Animal reservoirs for visceral leishmaniasis in densely populated urban areas
}

\author{
Soraia A. Diniz, ${ }^{1}$ Fabiana L. Silva, ${ }^{2}$ Alcina V. Carvalho Neta, ${ }^{2}$ Regina Bueno, ${ }^{3}$ \\ Rita M.S.N.C. Guerra, ${ }^{4}$ Ana L. Abreu-Silva, ${ }^{4}$ Renato L. Santos. ${ }^{2}$ \\ ${ }^{1}$ Secretaria Municipal de Saúde, Prefeitura Municipal de Ribeirão das Neves, Ribeirão das Neves, MG, Brazil \\ ${ }^{2}$ Departamento de Clínica e Cirurgia Vet., Escola de Veterinária, Universidade Federal de Minas Gerais, Belo Horizonte, MG, \\ Brazil. \\ ${ }^{3}$ Pontifícia Universidade Católica de Minas Gerais, Betim, MG, Brazil. \\ ${ }^{4}$ Universidade Estadual do Maranhão, São Luis, MA, Brazil.
}

\begin{abstract}
Leishmaniasis is a zoonotic disease of major public health and veterinary importance, affecting 88 countries with up to 2 million cases per year. This review emphasizes the animal reservoirs and spreading of visceral leishmaniasis (VL) in urban areas, particularly in two Brazilian metropolitan areas, namely São Luis and Belo Horizonte, where the disease has become endemic in the past few years. Urbanization of visceral leishmaniasis in Brazil during the last decades has created favorable epidemiological conditions for maintenance of the disease, with dense human populations sharing a tropical environment with abundant populations of the mammalian reservoir and the invertebrate vector, facilitating transmission of the disease.

Key Words: visceral leishmaniasis, Leishmania, animal reservoir.
\end{abstract}

J Infect Developing Countries 2008; 2(1):24-33.

Received 31 July 2007 - Accepted 2 January 2008.

Copyright (C) 2007 Diniz et al. This is an open access article distributed under the Creative Commons Attribution License, which permits unrestricted use, distribution, and reproduction in any medium, provided the original work is properly cited.

\section{Introduction}

Leishmaniasis is a zoonotic disease of major public health and veterinary importance. According to the World Health Organization, the visceral form of the disease is endemic in 88 countries distributed in four continents, with 1.5 to 2 million cases per year and 350 million people under risk of infection (WHO; http://www.who.int/tdr/ index.html). Human leishmaniasis in the Americas can be classified into two broad categories, namely American tegumentary leishmaniasis (TL) and American visceral leishmaniasis (VL) also known as "kala-azar". American TL may have several clinical manifestations, including (i) cutaneous leishmaniasis, characterized by skin lesions, which may heal spontaneously or progress to chronic lesions with severe scaring; (ii) mucocutaneous leishmaniasis, characterized by ulcerative and destructive lesions in mucous membranes and mucocutaneous junctions; and (iii) diffuse cutaneous leishmaniasis, characterized by non-ulcerative nodular lesions. Conversely, the visceral form of the disease is chronic and progressive, affecting several organs including the spleen, liver, bone marrow, lymph nodes, and skin.

Human VL has a wide distribution throughout Latin America, extending from Mexico to Argentina [1]. American VL is rapidly spreading in several regions of Brazil, and it is currently considered an urban disease. Migration of rural populations to periurban areas led to urbanization of the disease [2], since it created conditions in which the human population shared an environment with high densities of canine and invertebrate vector populations [3]. Environmental changes resulting in habitat destruction may have a significant impact on vector populations, with some species disappearing, and others becoming more abundant as some species can colonize and adapt to anthropogenic environmental conditions [2].

The distribution of American VL in Brazil includes the states of Alagoas, Bahia, Ceará, Distrito Federal, Espírito Santo, Goiás, Maranhão, Mato Grosso, Mato Grosso do Sul, Minas Gerais, Pará, Paraíba, Pernambuco, Piauí, Rio de Janeiro, Rio Grande do Norte, Roraima, Sergipe, São Paulo, and Tocantins [1] (Figure 1). There is a 
broad variation in the prevalence of $\mathrm{VL}$ among different regions in Brazil, with higher prevalence in the Northeastern part of the country (Figure 1). According to the Brazilian Ministry of Health (Fundação Nacional de Saúde - FUNASA; www.funasa.gov.br), from 1980 to 2005, there were 60,954 cases of VL registered in Brazil, with the highest number of cases in the States of Bahia $(16,635)$ and Maranhão $(8,484)$. Official records also indicate over 1,000 new human cases of VL yearly in Brazil. In the State of Maranhão, human and canine cases concentrate in the Island of São Luis (Figure 2), where there is a large urban area. In the last five years, 239 human cases of VL that led to 13 deaths and 7,682 canine cases were recorded (Center for Zoonosis Control of São Luis, unpublished data).

Figure 1. Distribution of human visceral leishmaniasis in Brazil. Cumulative number of cases from 1980 to 2005. Source of data: Brazilian Ministry of Health (MS/SVS, SES and SINAN).

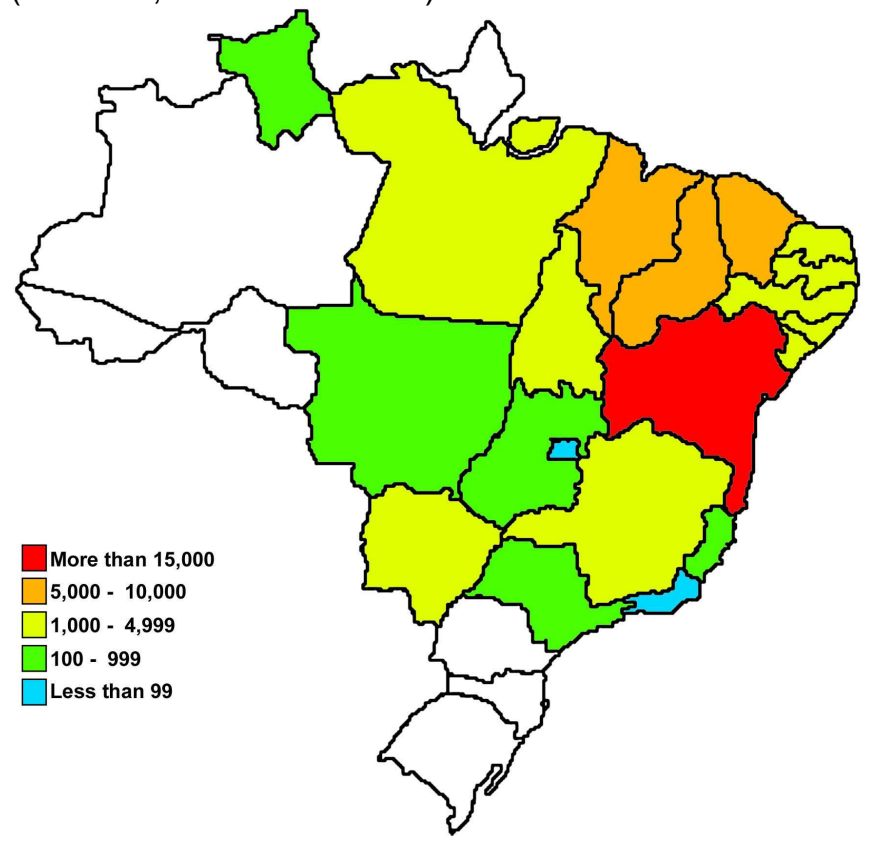

According to the Health Department of the State of Minas Gerais (SES/MG), 2,018 cases of human VL were confirmed in the state, resulting in 188 deaths (average lethality rate of $10.8 \%$ ) from 2000 to 2005. The cities of Belo Horizonte, Ribeirão das Neves and Santa Luzia (all part of the metropolitan area of Belo Horizonte), as well as Montes Claros and Janaúba (in the northern part of the State), and Paracatu (in the western part of the State) accounted for $51 \%$ of the cases.
The metropolitan area of Belo Horizonte (Figure 2 ), with an estimated population of more than three million people and an area of approximately 6,000 $\mathrm{Km}^{2}$, had the first case of human VL in 1994. After that first case, the disease spread quickly with 345 human cases of VL confirmed in that area between 1994 and 1999 [4].

Figure 2. Satellite view of the metropolitan areas of São Luis (State of Maranhão) and Belo Horizonte (State of Minas Gerais). Bar $=$ approximately $7 \mathrm{Km}$. Source: MIRANDA, E.E.; COUTINHO, A.C. (Coord.). Brasil Visto do Espaço. Campinas: Embrapa Monitoramento por Satélite, 2004. Available at: http://www.cdbrasil.cnpm.embrapa.br.

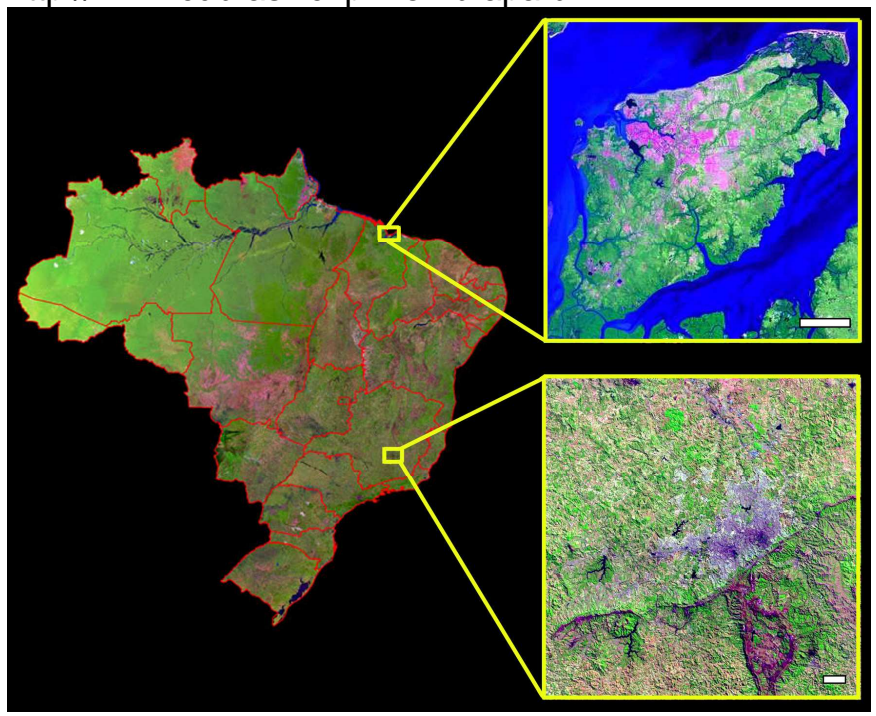

Here we review the literature and present some unpublished data with emphasis on animal reservoirs and the spread of $\mathrm{VL}$ in urban areas, particularly in two Brazilian metropolitan areas, namely São Luis and Belo Horizonte (Figure 2).

\section{Etiology of visceral leishmaniasis}

VL is caused by flagellated protozoa belonging to the order Kinetoplastida, family Trypanosomatidae and genus Leishmania. Human visceral leishmaniasis is caused by Leishmania donovani and Leishmania infantum in the Old World and Leishmania chagasi in the New World [reviewed by 5 and 6]: however, there is currently a tendency to consider $L$. infantum and $L$. chagasi as one single species [7].

Leishmania is a parasite that has heteroxeny during its life cycle so it has two hosts, one vertebrate (canids, rodents, and humans) and the other invertebrate sandfly (Order Diptera, Family 
Psychodidae, Sub-family Phlebotominae) belonging to the genus Phlebotomus in the Old World and the genus Lutzomyia in the New World, with one vector species, Lutzomyia longipalpis, in Brazil $[1,8,9]$.

Leishmania has distinct forms during its life cycle. Promastigotes and paramastigotes are flagellated and mobile, and they are present in the digestive tract of the invertebrate host, whereas the non-flagellated amastigotes (Figure 3), are found within phagocytic cells in the vertebrate host [10]. The infective form, named metacyclic promastigote is smaller with a longer flagellum when compared to the procyclic or non-infective form. Upon infection of the vertebrate host, the promastigotes undergo phagocytosis and become amastigotes, multiplying intracellularly until the host cell ruptures, releasing the parasite, which then infects other macrophages [11, 12]. The different clinical manifestations of the disease are determined by the species of the parasite as well as the immune condition of the host [11].

Figure 3. Bone marrow smear from a dog with a macrophage containing a myriad of amastigotes of Leishmania chagasi.

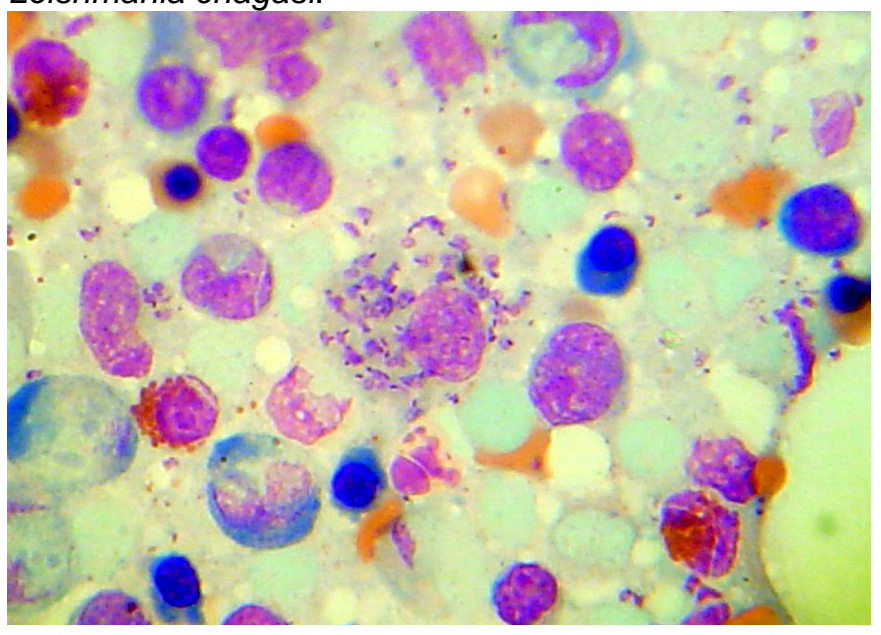

\section{Natural hosts and reservoirs of visceral leishmaniasis in metropolitan areas}

VL used to be restricted to rural and peri-urban areas in Brazil. However, with emergence of foci of the disease in urban areas, visceral leishmaniasis has assumed a major role in public health [13]. The domestic dog is the most important reservoir of $\mathrm{VL}$ in metropolitan areas. The dog develops an intense cutaneous parasitism, favoring infection of sandflies, thereby playing an important role in the epidemiological chain of VL [14]. Importantly, most dogs remain asymptomatic for long periods of time, which contribute to the maintenance and transmission of the disease, since the absence of clinical signs delays the diagnosis favoring the maintenance and transmission of VL. Indeed, it has been demonstrated that there is a significant correlation between the spatial distribution of seropositive dogs and human cases of $\mathrm{VL}$ in the metropolitan area of Belo Horizonte [15]. Furthermore, the geographic distribution of the first cases of canine VL in Belo Horizonte from 1993 and 1997 coincided with the emergence of human VL. Apparently under those conditions the establishment of human VL was preceded by infection of dogs in a given area [16].

There are no differences in predisposition among dogs of different ages or sexes. However, breed predisposition has been documented, with Cockers and Boxers having a higher risk when compared to other breeds [17]. Furthermore, dogs with short hair are predisposed when compared to those with long hair. The role of other species as reservoirs is not clear. For instance, natural infection of domestic cats with Leishmania has been documented [18]. In Europe, in addition to dogs, rodents are also identified as reservoirs, whereas humans and domestic cats are considered accidental hosts [19,20].

Environmental degradation associated with intensive migration of human populations from rural into urban areas favored urbanization of VL in Brazil. In the Island of São Luis, the first urban cases of human VL were identified in 1982 [21]. Concomitantly, the first cases of VL in dogs were reported in that region [22]. Initially, human and canine VL occurred in the periphery of the city of São Luis, but it gradually spread to other municipalities on the island (Paço do Lumiar, São José de Ribamar, and Raposa). The first cases of VL coincided with marked environmental changes and migration of rural human populations into the urban area. In addition, large industrial plants were established at that time, which stimulated influx of immigrants from other Northeastern Brazilian States where VL was endemic [23, 24]. Currently there are areas of the metropolitan region of São Luis with an extremely high seroprevalence in dogs, reaching $25 \%$ in one of the districts [25]. These high seroprevalences are associated with poor sanitation and housing conditions in areas previously occupied by the natural vegetation [26]. 
An ecoepidemiological study is currently underway in the Island of São Luis to identify risk factors for visceral leishmaniasis in that particular area.

Similarly, the first case of $V L$ in the metropolitan area of Belo Horizonte was diagnosed in 1994, and was followed by a fast spreading of the disease with 345 confirmed human cases from 1994 to 1999 [4]. In 2001, there were 31 cases of human VL reported, resulting in six deaths (Secretaria Municipal de Saúde de Belo Horizonte; http://www.pbh.gov.br/smsa/). In 2004, the number of human cases reached 128 with 21 deaths in the metropolitan area of Belo Horizonte, whereas in the whole State of Minas Gerais there were 587 cases with 49 deaths during the same period. Taking as an example Ribeirão das Neves, which is part of the Belo Horizonte metropolitan area, the first autochthonous case of VL was confirmed in 2000, with no cases reported in 2001 , but with a marked increase in the number of cases after 2002 (Figure 4). Interestingly, the increase in human cases of VL coincided with increases in seroprevalence in the canine population in the same area (Figures 4 and 5).

Figure 4. Number of confirmed cases and trend line of human visceral leishmaniasis in Ribeirão das Neves (metropolitan area of Belo Horizonte, State of Minas Gerais) from 1999 to 2006.

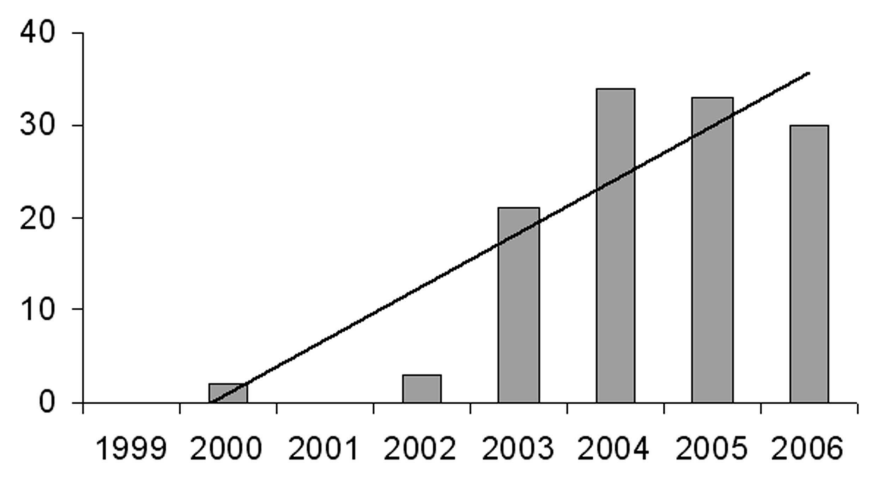

Although the dog is recognized as the major source of infection for the invertebrate vector and therefore potential transmission to humans [15, 2730], several species of wild canids, marsupials, and rodents have been incriminated as reservoirs in endemic areas [5]. However, the suitability of these species as reservoirs as well as their role in the epidemiology of $\mathrm{VL}$ remain to be investigated [1].
Figure 5. Number of samples of canine serum processed (black columns) and number of seropositive dogs (gray columns) from 2002 to 2006. The percentages indicate the frequency of seropositive dogs per year.

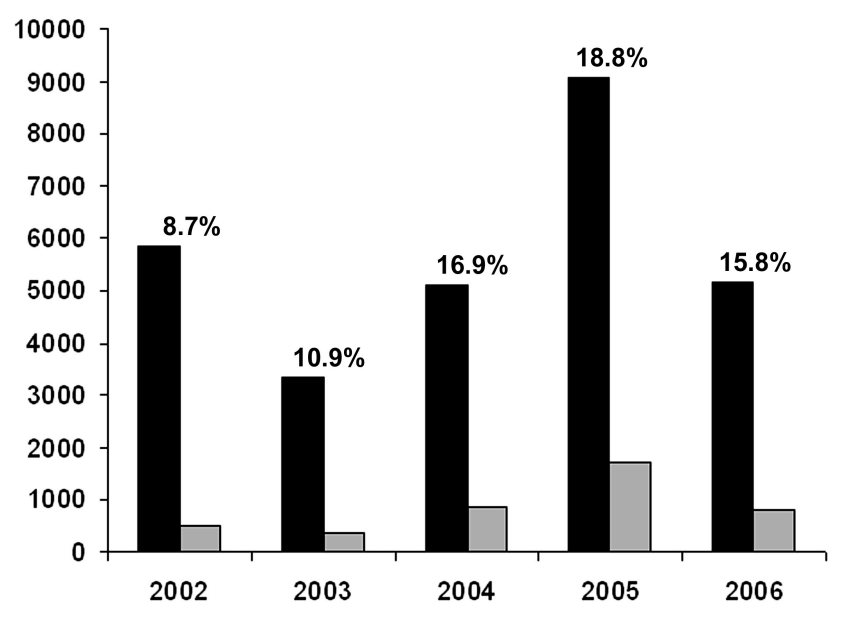

Several wildlife species from the Amazon rain forest in Brazil, including rodents, marsupials, procyonids, canids, and edentates have been surveyed for Leishmania infection. The parasite was detected only in the crab-eating fox (Cerdocyon thous) by culturing samples of the spleen and liver, and by inoculation in hamsters [31]. However, L. chagasi has been previously isolated from two opossums, Didelphis albiventris, captured in an endemic area in Jacobina (State of Bahia, Brazil), but the rate of infection was very low [32,33]. Furthermore, L. chagasi has been cultured from spleen, liver, and skin of the opossum (Didelphis marsupialis) in Colombia [34, 35]. In addition, infection of the rodent Proechimys canicolus has been demonstrated by PCR [36].

In order to be considered an effective reservoir of a parasite that is transmitted by a blood-suckling insect, in addition to playing a role in the maintenance and dissemination of the parasite under natural conditions, it is essential to demonstrate that the putative reservoir species effectively infects the invertebrate vector during the blood meal [1]. Considering these criteria, only Cerdocyon thous and Didelphis marsupialis are considered natural wild reservoirs of $L$. chagasi [35, 37].

Didelphis sp. is present in both São Luis and Belo Horizonte metropolitan areas where there is a high canine seroprevalence [25, 26]. However, although there is some evidence indicating that the 
presence of opossums is a predisposing factor for canine infection [38], the epidemiological role and the impact of the opossum as a reservoir of VL in urban areas is still not clear.

In spite of the fact that the dog is the major reservoir for human $\mathrm{VL}$, other animal species may play a significant role in the maintenance of the disease. These include chickens, pigs, cattle, and horses kept around the residences in urban areas, which favor proliferation of the vector and therefore transmission of the disease [39, 40]. Importantly, evaluation of the intestinal contents of $L$. longipalpis indicated that $24.4 \% \quad(n=547)$ fed on vertebrate blood, including avian (87.9\%); rodent (47.2\%); human (42.4\%); canine (27.6\%); opossum (26.6\%); and equine (22.5\%) blood [41].

\section{Transmission}

Transmission of VL generally takes place between the invertebrate vector and a mammalian host. A female phlebotominae sandfly vector is infected by ingesting amastigotes present in the dermis during the blood meal. The amastigotes transform into promastigotes within the digestive tract of the insect from 24 to 48 hours after the blood meal. The promastigotes then proliferate in the intestine and migrate to the esophagus and pharynx, and are regurgitated into the mammalian host during the blood meal [42]. Soon after inoculation the promastigotes are phagocytosed by machophages and locate inside a vacuole that fuses with lysosomes, named the parasitophorous vacuole $[10,43-45]$. The promastigotes then transform into amastigotes that replicate intracellularly eventually causing the rupture of the macrophage and thereby infecting other phagocytic cells $[10,46]$. Thus, control programs for VL must take into account the vectors, reservoirs, and susceptible hosts. Understanding the circumstances in which parasites are transmitted from dogs to sandflies is essential for implementing sound prophylactic measures [3].

The role of $L$. longipalpis as vector of AVL was first suspected in the 1930s when liver samples from patients suspected of yellow fever were diagnosed with VL. This first study performed in the Northeastern Brazilian State of Sergipe resulted in the description of the first clinical case of $\mathrm{VL}$ in a patient whose house had large numbers of L. longipalpis both indoors and outdoors [47]. Later on, other cases of human and canine VL were also linked to L. longipalpis [48]. However, the role of this sandfly as a vector for VL was initially characterized in the 1950s, when promastigotes of $L$. chagasi were detected in $L$. longipalpis, and infection occurred after exposure of foxes to infected sandflies [49-51]. At that time, the dog was identified as the main reservoir of the disease since $L$. longipalpis often became infected after feeding on infected dogs [27]. Subsequently, transmission of Leishmania was demonstrated in hamsters via the bite of experimentally infected laboratory-bred L. longipalpis [52]. The role of $L$. longipalpis was definitely established after identification of this sandfly as the only species present in the environment where cases of human LV were diagnosed, with sandflies from this particular area being able to infect hamsters [53, 54].

L. longipalpis was considered to be the only biological vector of $L$. chagasi for several years, but cases of VL began to be diagnosed in regions where this sandfly species was absent, indicating that other species could be transmitting the parasite to vertebrate hosts. Indeed, Lutzomyia evansi infected with $L$. chagasi was identified as the major vector for $\mathrm{VL}$ in certain areas of Colombia [55, 56] and Venezuela [57]. L. evansi is present in several Latin America countries including Costa Rica, Honduras, El Salvador, Guatemala [58] and Mexico [59], but it has not been detected in Brazil. Although there is evidence supporting the notion that Lutzomyia cruzi may act as an alternative vector for VL in Brazil [60], this view is still debatable [1].

L. longipalpis is the predominant sandfly species in São Luis, where it is abundant in the peridomestic environment [61-64]. This behavioral feature of $L$. longipalpis may partially explain the higher rates of infection in dogs than in humans [1]. Importantly, L. longipalpis has been captured indoors and outdoors in all areas with reported cases of human VL in São Luis. L. longipalpis is also the predominant species of sandfly in the metropolitan area of Belo Horizonte [65].

Although VL is largely recognized as an insectborne disease, there are several reports of transmission in the absence of the vector. For instance, the transmission through blood transfusions in human patients has been reported [66] as well as transmission by common use of needles among drug addicts [67]. Vertical 
transmission of Leishmania has been documented in humans [68]. Although a previous study failed to demonstrate vertical transmission in dogs [72], amastigotes of Leishmania have been detected in the uterus of a bitch with evidence of vertical transmission [69] and has been suggested by other investigators [70, 71]. Venereal transmission of $\mathrm{VL}$ has been documented between an infected man and his wife in an area completely free of the insect vector [73]. This form of transmission is also likely to occur in dogs [27]. We have recently demonstrated that dogs with VL develop specific genital lesions, namely epididymitis and balanopostitis, with an abundance of intralesional amastigotes. These lesions are associated with shedding of Leishmania in the semen, further supporting the notion of venereal transmission in dogs [74]. We are currently investigating whether venereal transmission actually occurs in dogs. Although the epidemiological significance of venereal transmission in dogs is merely speculative at this point, this form of transmission may have a significant impact in densely populated urban areas, particularly in Brazil where the vast majority of the canine population is not neutered.

\section{Impact of vaccination in dogs}

According to the World Health Organization, control measures for $\mathrm{VL}$ include reducing the population of the insect vector by massive application of insecticides, elimination of seropositive dogs, and early diagnosis and treatment of human cases [75]. In Brazil, the control of $V L$ is heavily based on elimination of positive dogs, and although this measure does have some effect on the number of human cases, it is not sufficient for eradication of the disease [75, 76]. In 2003, the Brazilian Ministry of Health made new recommendations for controlling $\mathrm{VL}$, including the control of the vector base on entomological surveys. Thus, application of insecticide that was previously performed within 300 meters of each confirmed human case, now is performed in areas classified as moderate or high risk of transmission, whereas areas free of the vector are not treated with insecticide and remain under entomological surveillance [77].

The control of canine $V L$ is based on the elimination of seropositive dogs; serological surveillance in areas with high or moderate risk of transmission; the use of collars impregnated with
$4 \%$ deltamethrin; the use of kennels with screens; and control of the population of stray dogs. However, treatment of canine VL is not recommended since it results only in improvement of clinical signs, but treated dogs remain a reservoir of the disease $[77,78]$.

A commercial vaccine against canine $V L$ is currently available in Brazil [79]. This vaccine has been approved by the Brazilian Ministry of Agriculture, which is responsible for evaluation and approval of therapeutic and prophylactic animal health products. However, the Brazilian Ministry of Health does not recommend vaccination of dogs for prevention of human VL, and proposes the elimination of seropositive dogs in areas with transmission of the disease even if the dog has been vaccinated ("Nota Técnica", May 09, 2005).

Recently, LiESAp-MDP, which is an experimental but not commercially available vaccine, had an efficacy of $92 \%$ in experimentally and naturally infected dogs in France, with protection lasting for 24 months [80]. The vaccine commercialized in Brazil has 79\% efficacy after 12 months of vaccination [79]. In Iran, another experimental vaccine that is a precipitate of Leishmania major associated with aluminum hydroxide and the BCG vaccine resulted in an efficacy of $69 \%$ [81].

Although in theory vaccination of dogs may have a significant impact in the occurrence of human VL, a drawback of the vaccine currently available in Brazil is that it does not allow for serological differentiation between infected and vaccinated dogs, which may eventually compromise the efficacy of the official programs for controlling VL.

\section{Future perspectives}

Human VL in Brazil affects mostly the lowincome class. Therefore, improving socioeconomic conditions is an essential step for effectively controlling the disease. According to Link and Felan [82], socioeconomic deprivation might be a "fundamental cause" of disease because it favors multiple risk factors. In fact, in the State of Maranhão, which has a low Human Development Index (HDI) and is the poorest state in Brazil (http://www.undp.org.br), has a high number of cases (Figure 1). VL has a complex correlation with poverty, involving factors such as poor housing and sanitation conditions, economically 
driven migration, poor nutrition, and the predisposition to other infectious diseases, which are features of the most heavily affected populations [reviewed by 83].

Poor sanitation is a factor that contributed to maintenance and dissemination of $V L$ in two districts of São José do Ribamar, the metropolitan area of São Luis [25]. Cases of human VL tend to have the same spatial pattern as irregular land occupations due to migratory fluxes [24]. Generally, the habitations are built near preexisting forests or non-developed areas, where there is a tendency for an abundance of the vector and reservoirs [26].

Other factors that may have a significant impact in controlling $V L$ in the future include the development of an insecticide with lower environmental impact and the development of new drugs that require a shorter therapeutic scheme and that are less toxic [84]. In addition, improvement of the currently available serological tests reducing the occurrence of false-negative results may also influence the efficacy of control programs. This could be achieved by using immunodominant antigens for serological detection, which may favor standardization of the assay and improvement of its sensitivity and specificity, particularly during the early stages of canine VL.

Urbanization of $\mathrm{VL}$ in Brazil during the last decades has created a very favorable epidemiological condition for maintenance of the disease, with dense populations of reservoirs, vector and humans sharing the same tropical environment that is extremely favorable for transmission of the disease. Thus, controlling VL under these conditions is an enormous challenge.

\section{References}

1. Lainson R, Rangel EF (2005) Lutzomyia longipalpis and eco-epidemiology of American visceral leishmaniasis, with particular reference to Brazil - A review. Mem Inst Oswaldo Cruz 100:811-827.

2. Berjarano EE, Uribe S, Rojas W, Vélez ID (2002) Phlebotomine sand flies (Diptera: Psychodidae) associated with the appearance of urban leishmaniasis in the city of Sincelejo, Colombia. Mem Inst Oswaldo Cruz 97:645-647.

3. Travi BL, Tabares CJ, Cadena H, Ferro C, Osório $Y$ (2001) Canine visceral leishmaniasis in Colombia: relationship between clinical and parasitologic status and infectivity for sand flies. Am J Trop Med Hyg 64:119-124.

4. Silva ES, Gontijo CMF, Pacheco RS, Fiuza VOP, Brazil RP (2001) Visceral leishmaniasis in the metropolitan region of Belo Horizonte, State of Minas Gerais, Brazil. Mem Inst Oswaldo Cruz 96:285-291.

5. Cardoso L, Cabral M (1998) Leishmania e leishmaniose canina. Rev Port Cienc Vet 527: 121-141.

6. Marsella R, Gopegui RR (1998) Leishmaniasis: a reemerging zoonosis. Int J Dermatol 37:801-814.

7. Mauricio IL, Howard MK, Stothard JL, Miles,MA (1999) Genomic diversity in the Leishmania donovani complex. Parasitol 119:237-246.

8. Vassilios JK (1993) Old World canine leishmaniasis. Coompend Cont Educ Pract Vet 15:941-949.

9. Grimaldi Jr. G, Tesh RB (1993) Leishmaniases of the New World: current concepts and implications for the future research. Clin Microbiol Rev 6:230-250.

10. Mauel J (1990) Macrophage-parasite interactions in Leishmania infections. J Leukoc Biol 47:187-193.

11. Chang KP (1990) Modern biology: cell biology of Leishmania. 2nd edition. New York: Farman.

12. Bueno R, Mello MN, Menezes CAS, Dutra WO, Santos $R L$ (2005) Phenotypic, functional, and quantitative characterization of canine peripheral blood monocytederived macrophages. Mem Inst Oswaldo Cruz 100:521524.

13. Marzochi MC, Marzochi KB, Carvalho RW (1994) Visceral leishmaniasis in Rio de Janeiro. Parasitol Today 10:37-40.

14. Giunchetti RC, Mayrink W, Genaro O, Carneiro CM, Correa-Oliveira R, Martins-Filho OA, Marques MJ, Tafuri WL, Reis AB (2006) Relationship between canine visceral leishmaniosis and the Leishmania (Leishmania) chagasi burden in dermal inflammatory foci. J Comp Pathol 135:100-107.

15. Oliveira CL, Assunção RM, Reis IA, Proietti FA (2001) Spatial distribution of human and canine visceral leishmaniasis in Belo Horizonte, Minas Gerais State, Brasil, 1994-1997. Cad Saude Publica 17: 1231-1237.

16. Bevilacqua PD, Paixão HH, Modena CM (2001) Urbanização da leishmaniose visceral em Belo Horizonte. Arq Bras Med Vet Zootec 53:1-8.

17. França-Silva JC, Costa RT, Siqueira AM, MachadoCoelho GLL, Costa CA, Mayrink W, Vieira EP, Costa JS, Genaro O, Nascimento E (2003) Epidemiology of canine visceral leishmaniosis in the endemic area of Montes Claros Municipality, Minas Gerais State, Brazil Vet Parasitol 111:161-173.

18. Savani ES, Camargo MCO, Carvalho MR (2004) The first record in the Americano of an autochthonous case of Leishmania (Leishmania) infantum chagasi in a cat (Felis catus) from Cotia County, São Paulo State, Brazil. Vet Parasitol 120: 229-233.

19. Kirkpatrick CE, Farrell JP, Goldschmidt MH (1984) Leishmania chagasi and L. donovani: experimental infection in domestic cats. J Exp Parasitol 58:125-131.

20. Poli P, Abramo F, Barsotti P, Leva S, Gramiccia M, Ludovisi A, Mancianti $F$ (2002) Feline leishmaniosis due to Leishmania infantum in Italy. Vet Parasitol 106:181191.

21. Silva AR (1995) Leishmaniose visceral no Estado do Maranhão: a evolução de uma epidemia. Cad Saude Publica 11:321-324.

22. Cardoso WM, Araujo RB, Quesada AM, Ferreira PM, Santos HM, Guimarães JM (1986) Leishmaniose visceral 
canina em São Luis, Maranhão. Alguns aspectos clínicos. Arq Bras Med Vet Zoot 38:27-31.

23. Costa JML, Viana GMC, Saldanha ACR, Nascimento MDSB, Alvim AC, Burattini MN, Silva AR (1995) Leishmaniose visceral no Estado do Maranhão: a evolução de uma epidemia. Cad Saude Publica 11:321324.

24. Mendes WS, Silva AAM, Trovão JR, Silva AR, Costa JML (2002) Expansão espacial da leishmaniose visceral americana em São Luis, Maranhão, Brasil. Rev Soc Bras Med Trop 35:227-231.

25. Guimarães KS, Batista ZS, Dias EL, Guerra RMNC, Costa ADCC, Oliveira AS, Calabrese KS, Cardoso FO, Souza CSF, Zaverucha do Vale T, Gonçalves da Costa SC, Abreu-Silva AL (2005) Canine visceral leishmaniasis in São José de Ribamar, Maranhão State, Brazil. Vet Parasitol 131:305-309.

26. Oliveira AC, Abreu-Silva AL, Lima TB, Silva APC, Reis LF, Barbosa DS, Guerra RMSNC (2006) Soroprevalência da leishmaniose visceral canina no bairro Jardim São Raimundo em São Luís. Rev Soc Bras Med Trop Suppl $1: 140-143$.

27. Deane LM (1958) Epidemiologia e profilaxia do Calazar Americano. Rev Bras Malariol Doencas Trop 10:431449.

28. Iverson LB, Camargo ME, Villanova $A$, Reichmann MLAB, Andrade EA, Tolezano JE (1983) Inquérito sorológico para pesquisa de leishmaniose visceral em população canina-urbana do município de São PauloBrasil (1979-1982). Rev Inst Med Trop Sao Paulo 25:310317.

29. Marzochi MC, Coutinho SG, De Souza WJ, De Toledo LM, Grimaldi Jr. G, Momem H, Pacheco RS, Sabroza PC, De Souza MA, Rangel Jr. FB (1985) Canine visceral leishmaniasis in Rio de Janeiro. Brazil. Clinical, Parasitological, therapeutical and Epidemiological findings (1977-1983). Mem Inst Oswaldo Cruz 80:349357.

30. Tesh RB (1995) Control of zoonotic visceral leishmaniasis: Is time to change strategies? Am J Trop Med Hyg 52:287-292.

31. Lainson R, Shaw, JJ Silveira, FT Braga, RR (1987) American visceral leishmaniasis: on the origin of Leishmania (Leishmania) chagasi. Trans R Soc Trop Med Hyg 81:517.

32. Sherlock IA, Miranda JC, Sadigursky M, Grimaldi G (1984) Natural infection of the opossum Didelphis albiventris (Marsupialia: Didelphidae) with Leishmania donovani in Brazil. Mem Inst Oswaldo Cruz 79:511.

33. Sherlock IA, Miranda JC, Sadigursky M, Grimaldi, G (1988) Observações sobre calazar em Jacobina, Bahia. VI. Investigações sobre reservatórios silvestres e comensais. Rev Soc. Bras Med Trop 21:23-27.

34. Corredor A,Gallego JF, Tesh RB, Peláez D, Diaz A, Montilla M, Paláu MT (1989) Didelphis marsupialis, an apparent wild reservoir of Leishmania donovani chagasi in Colombia, South America, Trans R Soc Trop Med Hyg 83:195.

35. Travi BL, Osorio $\mathrm{Y}$, Guarin $\mathrm{N}$, Cadena $\mathrm{H}$. (1998).Leishmania (Leishmania) chagasi): clinical and parasitological observations in experimentally Didelphis marsupialis, reservoir of New World visceral leishmaniasis. Exp Parasitol 88:73-75.
36. Travi BL, Osorio $\mathrm{Y}$, Becerra MT, Adle $\mathrm{GH}$. (1998)Dynamics of Leishmania chagasi infection in small mammals of the undisturbed and degraded tropical dry forests of northern Colombia. Trans R Soc Trop Med Hyg 92:275-278.

37. Lainson R, Dye C, Shaw JJ, MacDonald DW, Courtenay O, Souza AAA, Silveira, FT (1990) Amazonian visceral leishmaniasis - Distribution of the vector Lutzomyia Longipalpis (Lutz \& Neiva) in relation to the fox Cerdocyon thous (Linn) and the efficiency of this reservoir host as a source of infection. Mem Inst Oswaldo Cruz 85:435-443.

38. Cabrera MAA, Paula AA, Camacho LAB, Marzochi MCA, Xavier SC, Silva AVM, Jansen AM (2003) Canine visceral leishmaniasis in Barra de Guaratiba, Rio de Janeiro, Brazil: assessment of risk factors. Rev Inst Med Trop Sao Paulo 45:79-83.

39. Alexander $B$, Carvalho $R L$, Mccallum $H$, Pereira $M H$ (2002) Role of the domestic chicken (Gallus gallus) in the epidemiology of urban visceral leishmaniasis in Brazil. Emerg Infect Dis 8:1480-1485.

40. Dantas-Torres F, Brandão-Filho SP (2006) Visceral leishmaniasis in Brazil: revisiting paradigms of epidemiology and control. Rev Inst Med Trop Sao Paulo 48:151-156.

41. Dias FOP, Lorosa ES, Rebelo JMM (2003) Fonte alimentar sangüínea e a peridomiciliação de Lutzomyia longipalpis (Lutz \& Neiva, 1912) (Psychodidae, Phlebotominae).Cad Saude Publica19:1373-1380.

42. Kamhawi S (2006) Phlebotomine sand flies and Leishmania parasites: friends or foes? Trends Parasitol 22: 439-445.

43. Russell DG, Talamas-Rohana P (1989) Leishmania and macrophage: a marriage of inconvenience. Immunol. Today 10:328-333.

44. Mosser DM, Rosenthal LA (1993) Leishmaniamacrophage interactions: multiple receptors, multiple ligands and diverse cellular responses. Cell Biol 4:315322.

45. Pearson RD, Sousa AQ (1996) Clinical spectrum of leishmaniasis. Clin Infect Dis 22:1-13.

46. Handman E, Bullen DVR (2002) Interaction of Leishmania with the host macrophage. Trends Parasitol 18:332-334.

47. Chagas, E (1936) Primeira verificação em indivíduo vivo, da leishmaniose visceral no Brasil. Bras Med 50:221-22.

48. Chagas E, Cunha AM, Fereira LC, Deane L, Deane MD, Guimarães FN, Paumgarten, MJ (1938) Leishmaniose visceral americana (Relatório de trabalhos realizados pela Comissão Encarregada do Estudo da Leishmaniose Visceral Americana em 1937). Mem Inst Oswaldo Cruz 33:89-229.

49. Deane MP, Deane LM (1954) Infecção natural do Phlebotomus longipalpis por leptomonas, provavelmente Leishmania donovani, em foco de calazar, no Ceará. Hospital 45:697-702.

50. Deane MP, Deane LM (1954) Encontro de leishmanias nas vísceras e na pele de uma raposa, em zona endêmica de calazar, nos arredores de sobral, Ceará, Hospital 45:419-421.

51. Deane MP, Deane LM (1954) Infecção experimental do Phlebotomus longipalpis em raposa (Lycalopex vetulus) 
naturalmente parasitada pela Leishmania donovani. Hospital, 46:651-653.

52. Lainson R, Ward RD, Shaw J (1977) Experimental transmission of Leishmania chagasi causative agent of neotropical visceral leishmaniasis, by the sandfly Lutzomyia longiplapis. Nature, 266:628-630.

53. Lainson R, Shaw, JJ Ryan, L, Ribeiro RSM., Silveira FT (1984) Presente situação da leishmaniose visceral na Amazônia, com especial referência a um novo surto da doença ocorrido em Santarém, Estado do Pará. Brasil. Bol Epidemiol ESESP, Rio de Janeiro (special issue):1-8.

54. Lainson R, Shaw JJ, Ryan, L Silveira, FT (1985) Leishmaniasis in Brazil XXI. Visceral leishmaniosis in the Amazon Region and further observations on the role of Lutzomyia longipalpis (Lutz \& Neiva, 1912) as a vector. Trans R Soc Trop Med Hyg 79:223-226.

55. Travi BL, Vélez ID, Brutus L, Segura I, Jaramillo C, Montoya J (1990) Lutzomyia evansi, an alternative vector of Leishmania chagasi in a Colombian focus of visceral leishmaniasis. Trans R Soc Trop Med Hyg 84:676-677.

56. Travi BL, Montoya J, Gallego J, Jaramillo C, Llano R, Vélez ID (1996) Bionomics of Lutzmyia evansi (Diptera: Psychodidae), vector of visceral leishmaniasis in Northern Colombia. J Med Entomol 33:278-285.

57. Aguilar CM., Fernández E, Cannova DC, Ferrer E, Cabrera Z, Souza WJS, Coutinho SG (1998) Urban visceral leishmaniasis in Venezuela. Mem Inst Oswaldo Cruz 93:15-16.

58. Young DG, Duncan, MA (1994) A guide to the identification and geographic distribution of Lutzomyia sand flies in Mexico, the West Indies, central and South America (Diptera: Psychodidae). Mem Am Entomol 54:1881.

59. Ibáñez-Bernal S, Rodrigues-Dominguez G., GómezHernández CH, Ricardez-Esqyine Jr. (2004) First record of Lutzomyia evansi (Nuñez-Tovar 1924) in México (Diptera: Psychodidae: Phleotominae). Mem Inst Oswaldo Cruz 99:127-129.

60. Santos SO, Arias JR, Rieiro AA, Hoffmann MP, Freitas,RA, Malacco MAF (1988) Incrimination of Lutzomyia cruzi as vector of American visceral leishmaniasis. Med Vet Ent 12:315-317.

61. Barros VL, Rebêlo JM, Silva FS (2000) Sandflies (Diptera, psychodidae) in a secondary forest area in the Paco do Lumiar city, Maranhao, Brazil: a leishmaniasis transmission area. Cad Saude Publica 16:265-270.

62. Carvalho ML, Rebêlo JM, M, Araújo JC, Barros VLL (2000). Aspectos ecológicos dos flebotomíneos (Díptera, Psychodidae) do Município de São José de Ribamar, MA, Brasil. Área endêmica de leishmanioses. Entomol Vet 7:19-32.

63. Rebêlo JM, Leonardo FS, Costa JM, Pereira YN, Silva FS (1999) Sandflies (Diptera, Psychodidae) from an endemic leishmaniasis area in the cerrado region of the State of Maranhão, Brazil. Cad Saude Publica 15:623630.

64. Penha TA, Abreu-Silva AL, Rebelo JMM, Oliveira AC, Santos ACG, Moraes JL, Guerra RMSNC (2006) Flebotomíneos em áreas endêmicas de leishmaniose visceral canina no município de São Luís. Rev Soc Bras Med Trop Suppl 1:77.

65. Souza CM, Pessanha JE, Barata RA, Monteiro EM, Costa DC, Dias ES (2004) Study on phlebotomine sand fly (Diptera: Psychodidae) fauna in Belo Horizonte, state of Minas Gerais, Brazil. Mem Inst Oswaldo Cruz 99:795803.

66. Otero ACS, Silva VO, Luz KG, Palatinik M, Pirmez C, Fernandes O, Souza CP (2000) Occurrence of Leishmania donovani DNA in donated blood from seroreactive Brazilian blood donors. Am J Trop Med Hyg 62:128-131.

67. Bosch RJ, Rodrigo AB, Sánchez P, Gálvez MV, Herrera $E$ (2002) Presence of Leishmania organisms in specific and non-specific skin lesions in HIV-infected individuals with visceral leishmaniasis. Int J Dermatol 41:670-675.

68. Low GC, Edin MD, Lond FRCP, Cooke WE, Irel FRCS (1926) A congenital case of Kala-azar. Lancet 11:12091211.

69. Rosypal AC, Troy GC, Zajac AM, Frank G, Lindsay DS (2005) Transplacental transmission of a North American isolate of Leishmania infantum in a experimentally infected beagle. J Parasitol 91:970-972.

70. Masucci M, De Majo M, Contarino RB, Borruto G, Vitale F, Pennisi MG (2003) Canine leishmaniasis in the newborn puppy. Vet Res Commun 27(Suppl.1):771-774.

71. Dubey JP, Rosypal AC, Pierce V, Scheinberg SN, Lindsay DS (2005) Placentitis associated with leishmaniasis in a dog. J Am Vet Med Assoc 227:12661269.

72. Andrade HM, Toledo VPCP, Marques MJ, Silva JCF, Tafuri WL, Mayrink W, Genaro O (2002) Leishmania (Leishmania) chagasi is not vertically transmitted in dogs. Vet Parasitol 103:71-81.

73. Symmers WSC (1960) Leishmaniasis acquired by contagion a case of marital infection: in Britain. Lancet 16:127-132.

74. Diniz SA, Melo MS, Borges AM, Bueno R, Reis BP, Tafuri WL, Nascimento EF, Santos RL (2005) Genital lesions associated with visceral leishmaniasis and shedding of Leishmania sp. in the semen of naturally infected dogs. Vet Pathol 42:650-658.

75. Ashford DA, David JR, Freire M, David R, Sherlok I, Eulálio MC, Sampaio DP, Badaró R (1998) Studies on control of visceral leishmaniasis: impact of dog control on canine and human visceral leishmaniasis in Jacobina, Bahia, Brazil. Am J Trop Med Hyg 59: 53-57.

76. Oliveira SS, Araújo TM (2003) Avaliação das ações de controle de leishmaniose visceral (Calazar) em uma área endêmica do Estado da Bahia, Brasil (1995-2000). Cad Saude Publica 19: 1681-1690.

77. Manual de vigilância e controle da leishmaniose visceral. Brasília: Ministério da Saúde, 2006. 120p.

78. Guerin PJ, Olliaro P, Sundar S, Boelaert M, Croft SL, Desjeux P, Wasunna MK, Bryceson ADM (2002) Visceral leishmaniasis: current status of control, diagnosis and treatment, and proposed research and development agenda. Lancet 2: 494-501.

79. Saraiva EM, Barbosa AF, Santos FN, Borja-Cabrera GP, Nico D, Souza LOP, Mendes-Aguiar CO, Souza EP, Fampa P, Parra LE, Menz I, Dias Jr. JG, Oliveira SM, Palatnik-De-Sousa CB (2006) The FML-vaccine (Leishmune) against canine visceral leishmaniasis: A transmission blocking vaccine. Vaccine 24:2423-2431.

80. Lemesre JL, Holzmuller P, Gonçalves RB, Bourdoiseau G, Hugnet C, Cavaleyra M, Papierok G (2007) Longlasting protection against canine visceral leishmaniasis 
using the LiESAp-MDP vaccine in endemic areas of France: Double-blind randomised efficacy field trial. Vaccine 25:4223-4234.

81. Mohebali M, Khamesipour A, Mobedi I, Zarei Z, HashemiFesharki R (2004) Double-blind randomized efficacy field trial of alum precipitated autoclaved Leishmania major vaccine mixed with BCG against canine visceral leishmaniasis in Meshkin-Shahr district, I.R. Iran. Vaccine 22:4097-4100.

82. Link BG, Phelan J (1995) Social conditions as fundamental causes of disease. J Health Soc Behav Spec No:80-94.

83. Alvar J, Yactayo S, Bern C (2006) Leishmaniasis and poverty. Trends Parasitol 22:552-557.

84. Deusjeux $P$ (2004) Leishmania: current situation and new perspectives. Comp Immunol Microbiol Infect Dis 27:305318.
Corresponding Author: Renato L. Santos, Escola de Veterinária da UFMG, Depto. Clínica e Cirurgia Vet., Av. Antonio Carlos, 6627, 31270-901 Belo Horizonte, MG, Brazil, Phone: 55-31-3499-2239, Fax: 55-31-34992230,Email: rsantos@vet.ufmg.br

Conflict of interest: No conflict of interest is declared. 